\title{
切欠，角変形，殘留応力 脆性破壊発生特性に及ぼす影響（第2報）
}

$-80 \mathrm{~kg} / \mathrm{mm}^{2}$ 級高張力鋼溶接継手に対する検討—

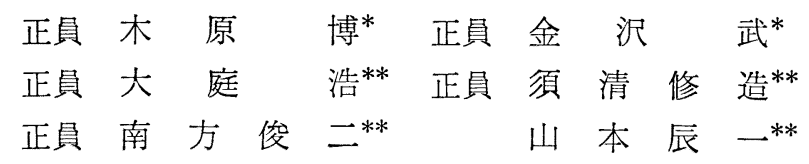

Effects of Notch Size, Angular Distortion and Residual Stress on Brittle Fracture Initiation Characteristics of Welded Joints for High Strength Steels (The 2 nd Report)

_Experimental Research for Welded Joint of $80 \mathrm{~kg} / \mathrm{mm}^{2}$ High Strength Stee1__

By Hiroshi Kihara, Member Takeshi Kanazawa, Member
Hiroshi Ōba, Member Shūzo Susei, Member
Shunji Minakata, Member Shin-ichi Yamamoto

Summary

In this paper, for the purpose of reproducing brittle fracture at low stress levels in the welded joints of $80 \mathrm{~kg} / \mathrm{mm}^{2}$ high strength steel, we have carried out a systematic investigation on fracture load conditions of surface notched wide tension test specimens, continued from the previous report about $60 \mathrm{~kg} / \mathrm{mm}^{2}$ high strength steel.

Further, we considered to obtain a substantiation of fracture conditions, and suggestions for the prevention of similar troubles in future, by application of fracture mechanics for various experimental fracture conditions.

The main results obtained are summarized as follows.

(1) Brittle fracture in the welded joint of $80 \mathrm{~kg} / \mathrm{mm}^{2}$ high strength steel was reproduced below yield stress levels in practical service temperature regions, by the superposition of various actual stress concentration factors such as a surface notch, angular distortion of the welded joint, welding residual stress, etc.

(2) Stress concentration factors are severer, the fracture transition region and stress transition region in wide tension test specimens are closer to each other.

(3) By application of Irwin's fracture mechanics it was possible to analyse the experimental results approximately, although the brittle fracture initiation was in a considerably high temperature region.

(4) Even when various stress concentration factors are present in superposition, it is possible to prevent the fracture initiation of the welded structure under low loading condition by mechanical stress relieving such as preloading in the higher-temperature region than the service temperature.

\section{1. 緒}

言

前報において ${ }^{1)}, 60 \mathrm{~kg} / \mathrm{mm}^{2}$ 級調質高張力鋼の溶接継手における使用温度域での低荷重脆性破壊の再現と各種

* 東京大学工学部船舶工学科

** 川崎重工業 (株) 技術研究所 
応力集中要因の影響度を明らかにすることができた。本報に出いては，引続いて商用の $80 \mathrm{~kg} / \mathrm{mm}^{2}$ 級調質高張

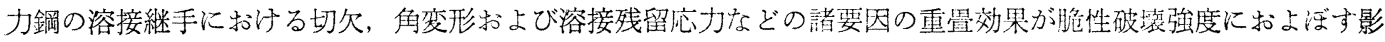
響について広幅試験片を用いて系統的に実験を行なつた。さらに鈋における種々の破壊の条件に対して破壊力 学の適用を試み，破壞発生条件の裏付けと今後の同種の事故防止に対して示唆を得るよら試みた。また，奏際的 な欠陷としての非貫通切欠ょりの脆性破壞発生条件ならびに応力遊移と破面遷移現象の相関についても若干の考 察を試㕛た。

\section{2. 供 試 材}

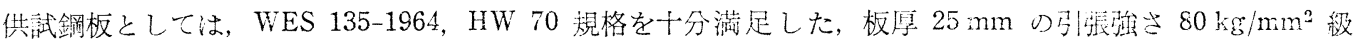

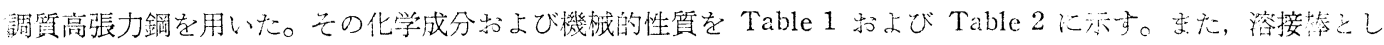

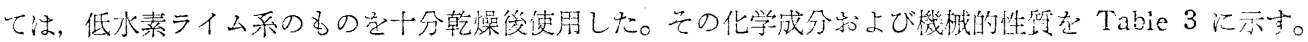

Table 1 Chemical compositions of steel used

\begin{tabular}{|c|c|c|c|c|c|c|c|c|c|c|c|c|}
\hline \multirow{2}{*}{\multicolumn{2}{|c|}{ Steel }} & \multicolumn{10}{|c|}{ Chemical Composition (ladle, \%) } & \multirow{2}{*}{$\begin{array}{l}\text { Ceq. * } \\
\text { (WES) }\end{array}$} \\
\hline & & $\mathrm{C}$ & $\mathrm{Si}$ & $\mathrm{Mn}$ & $\mathrm{P}$ & $\mathrm{S}$ & $\mathrm{Cu}$ & $\mathrm{Ni}$ & $\mathrm{Cr}$ & Mo & B & \\
\hline $\begin{array}{c}\text { HT } 80 \\
(\text { River Ace } \mathrm{K} \cdot \mathrm{O})\end{array}$ & $t=25 \mathrm{~mm}$ & 0.14 & 0.30 & 1.07 & 0.008 & 0.007 & 0.19 & 0.33 & 0.54 & 0.300 & 0.004 & 0.52 \\
\hline
\end{tabular}

Remarks $*$; Ceq. $(\%)=\mathrm{C}+\frac{\mathrm{Mn}}{6}+\frac{\mathrm{Si}}{24}+\frac{\mathrm{Cr}}{5}+\frac{\mathrm{Ni}}{40}+\frac{\mathrm{Mo}}{4}+\frac{\mathrm{V}}{1.4}$

Table 2 Mechanical properties of steel used

\begin{tabular}{c|c|c|c}
\hline $\begin{array}{c}\text { Yield Point* } \\
\left(\mathrm{kg} / \mathrm{mm}^{2}\right)\end{array}$ & $\begin{array}{c}\text { Tensile* } \\
\text { Strength } \\
\left(\mathrm{kg} / \mathrm{mm}^{2}\right)\end{array}$ & $\begin{array}{c}\text { Elong. } \\
\left(\mathrm{G} . \mathrm{L} . \begin{array}{l}=50 \mathrm{~mm}) \\
(\%)\end{array}\right.\end{array}$ & $\begin{array}{c}\text { V-Charpy } \\
\text { Impact Value } \\
\mathrm{E}_{-15}(\mathrm{~kg}-\mathrm{m})\end{array}$ \\
\hline 79.0 & 84.0 & 24.0 & 20.5 \\
\hline
\end{tabular}

Remarks *; by JIS No. 4 test piece

Table 3 Chemical compositions \& mechanical properties of electrodes used

\begin{tabular}{|c|c|c|c|c|c|c|c|c|c|c|c|}
\hline \multirow[b]{2}{*}{ Electrode } & \multicolumn{6}{|c|}{ Chemical Compositions (\%) } & \multicolumn{4}{|c|}{ Mechanical Properties } & \multirow[b]{2}{*}{$\begin{array}{c}\text { Welding } \\
\text { Heat } \\
\text { Input } \\
(\text { Joule } / \mathrm{cm})\end{array}$} \\
\hline & $\mathrm{C}$ & $\mathrm{Si}$ & $\mathrm{Mn}$ & $\mathrm{P}$ & $\mathrm{S}$ & $\mathrm{Ni}$ & $\begin{array}{c}\text { Yield } \\
\text { Point } \\
\left(\mathrm{kg} / \mathrm{mm}^{2}\right)\end{array}$ & $\begin{array}{l}\text { Tensile* } \\
\text { Strength } \\
\left(\mathrm{kg} / \mathrm{mm}^{2}\right)\end{array}$ & $\begin{array}{c}\text { Elong. } \\
\left(\begin{array}{c}\text { G. L. }= \\
50 \mathrm{~mm} \\
(\%)\end{array}\right) \\
\end{array}$ & $\begin{array}{c}\text { V-Charpy } \\
\text { Impact } \\
\text { Value } \\
\mathrm{E}_{-30}(\mathrm{~kg}-\mathrm{m})\end{array}$ & \\
\hline $\begin{array}{c}\mathrm{KS} 116 \\
(4 \phi)\end{array}$ & 0.06 & 0.61 & 1.39 & 0.014 & 0.008 & 2.29 & - & 86.0 & 25.0 & 8.4 & $15,000 \sim$ \\
\hline $\begin{array}{c}\mathrm{KS} 116 \\
(5 \phi)\end{array}$ & 0.07 & 0.59 & 1. 43 & 0.015 & 0.010 & 2.19 & - & 85.0 & 24.0 & 9.2 & 20,000 \\
\hline
\end{tabular}

Remarks *; by JIS No. 1 test piece

\section{3. 試 験 方法}

試験に供した広幅試験片の形状は，前報と同様幅 $400 \mathrm{~mm}$, 長さ $500 \mathrm{~mm}$ のもので十字溶接継手の水平秤手部 （中央部）に板厚方向に非貫通な半楕円型表面切欠を有し，かつ同継手を折れ線として試験片が角变形したもの

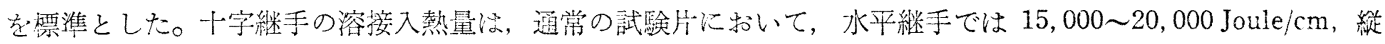
継手では 45,000〜 50,000 Joule/cm の範四に収まるよら考虑した。

切欠は先端半径が $0.1 \mathrm{~mm}$ の saw cut notch とし，その先端は熱影響ボンド部に位置するよらにした。さた，

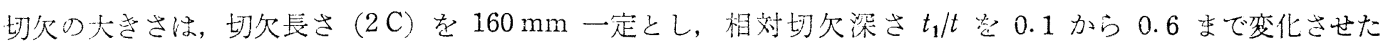
$\left(t=\right.$ 板厚, $t_{1}=$ 切欠の板表面よりの深さ)。

試験片の角变形量は主に $\theta / 2=30 / 1000$ (試験片の折れ曲り量が $15 \mathrm{~mm}$ ) とし，一部に 40/1000を採用した。 
試験は，溶接完了後 10 日経過してから実施し $+10^{\circ} \mathrm{C} \sim-100^{\circ} \mathrm{C}$ の温度範困で行なつた。

以上の広幅試駼以外に圾駗結果を考察し，解析する上で基礎となる Deep Notch Test および温度勾配型 ESSO 試験を实施した。また小型試験としてはシャルピー衝撃試験, Tipper 試験ならびに低温丸棒引張試験を実施し, た。

\section{4. 試験結果むよび考察}

\section{1 各種要因の破壊応力におよぼす影響}

(1) 切火深さの影響

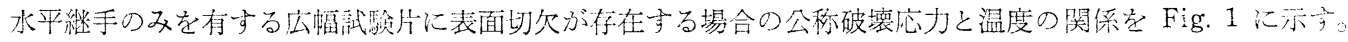

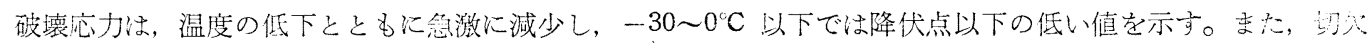
深岂の影響は, 切久深さが增加与るほど顕著となつている。

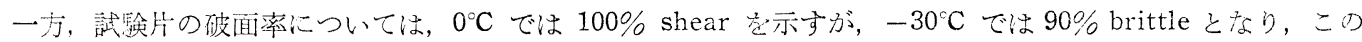

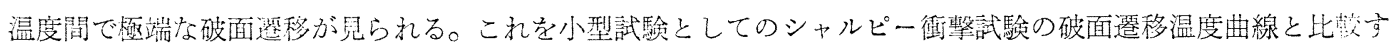

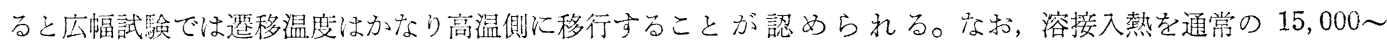

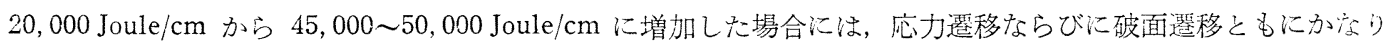
高温側江移行している。

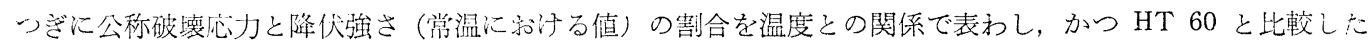
ものを Fig. 2 に示すが，これによると HT 60 に比べ HT 80 では 80 〜 $100^{\circ} \mathrm{C}$ 程度高温側で破壞灾力の遷垑が 見的

（2）切久怙よび角变形の重畳する場合の影響

水平継手の中央に表面切欠があり，かつ角恋形が重畳している場合の公称破壞応と温度の関係を Fig. 3 に 示守。

切久深さ $t_{1} / t=0.2$ を一定にし, 初期角変形量 $(\theta / 2)$ を $30 / 1000,40 / 1000$ の 2 段階に変化させた場合, $0^{\circ} \mathrm{C}$

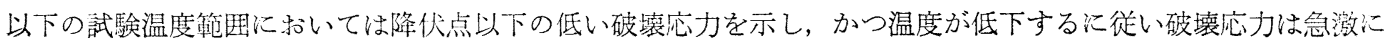
減少吉る。

また变形量が大きい注ど破壊応力は低くなり，両者の間汇遷移温度にして約 $10^{\circ} \mathrm{C}$ の差が見られる。まな，

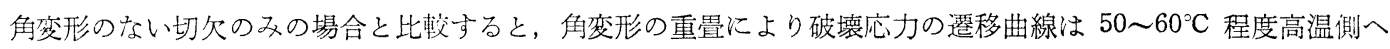
移り，しかも破罗応力レベルとしては $-60^{\circ} \mathrm{C}$ に括いて前者の $1 / 2$ 以下となり，かつ $1 / 2 \sigma_{y}$ を下廻る低い值と なつている。

また，破面率については，破壊灾力としては此較的高い值を示す $-10^{\circ} \mathrm{C}$ 前後の温度域化いて，すでに $80 \%$ brittle 定示し, $0^{\circ} \mathrm{C}$ 以上の常温域での破面遙移現象が予測される。

つぎに圾験結果を HT 60 と比顿すると，Fig. 4 から明らかなように HT 80 ではHT 60 より破壊応力曲線 法 $30 \sim 40^{\circ} \mathrm{C}$ 程度高温側化位置することが認められる。

（3）切欠および角变形が重畳し，から溶接入熱が变化した場合の影響

溶接入熱量を通常の $15,000 \sim 20,000$ Joule/cm から 45, 000 50, 000 Joule/cm 飞增加した場合の結果を Fig. 5 および Fig. 6 に示す。

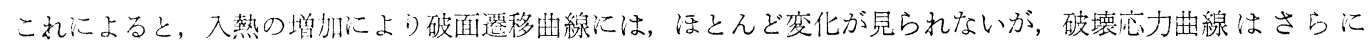
10〜20 $0^{\circ}$ 高温側へ移行与ることが愁奶られる。

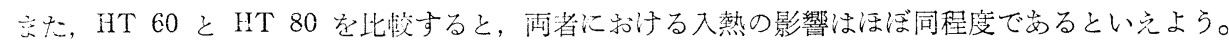

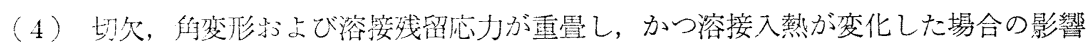

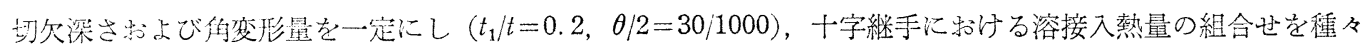

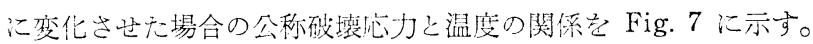

これによると, 水平継手, 縦継手とも小入熱の場合, 最も高い破壞応力を示しているが, 常温汇和いても降伏

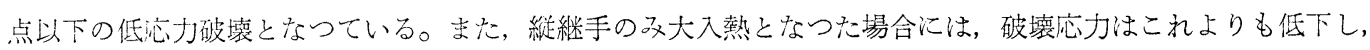
さらに, 両継手とも大入熱の場合には, さらに低い破壊応力を示し, 常温に拈いても降伏点のほぼ $1 / 2$ になつて いる。すなわち，HT 60 の場合には前報で示したように，十字継手においては継手の入熱変化に上る影響は， 

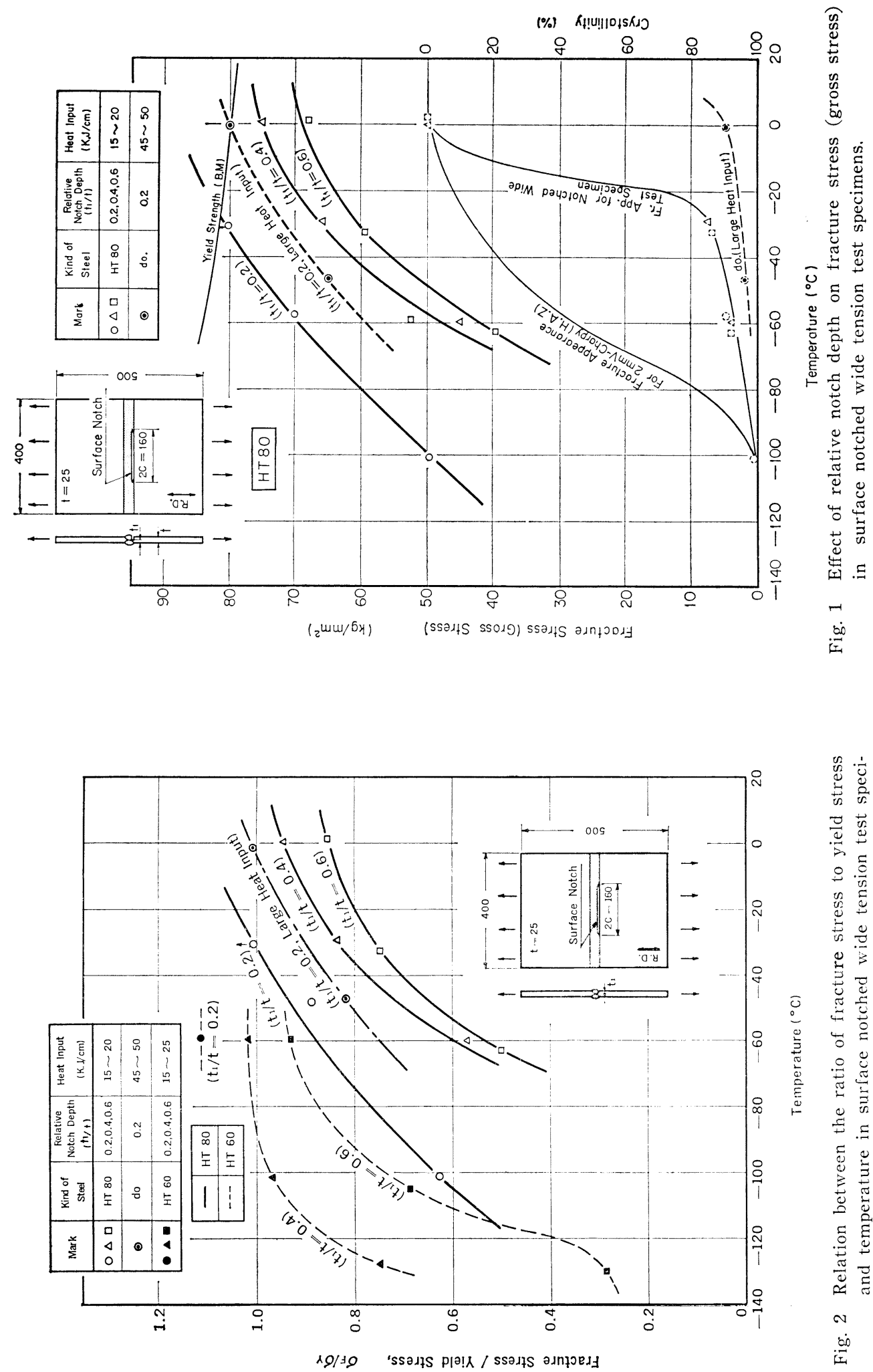

告 

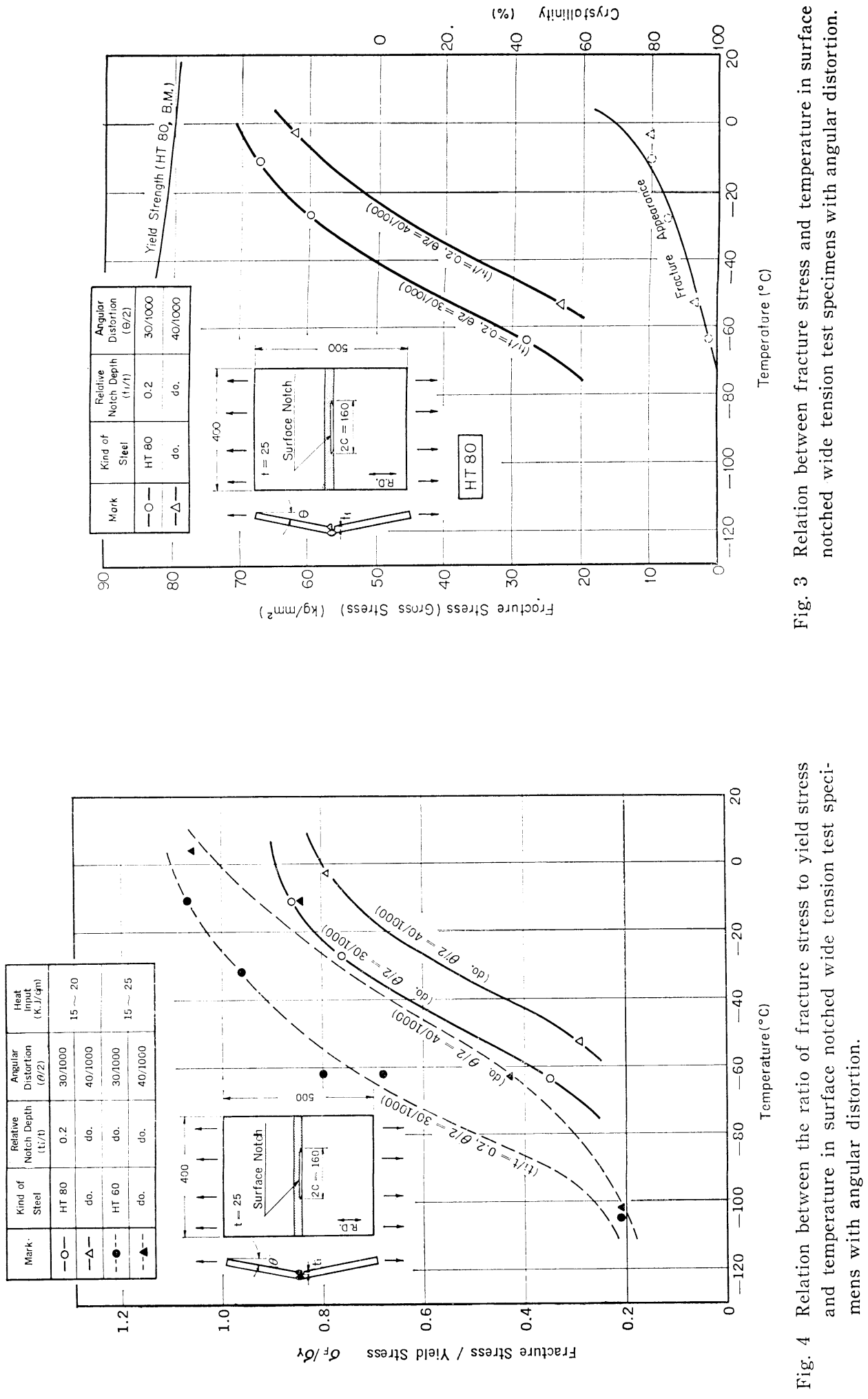

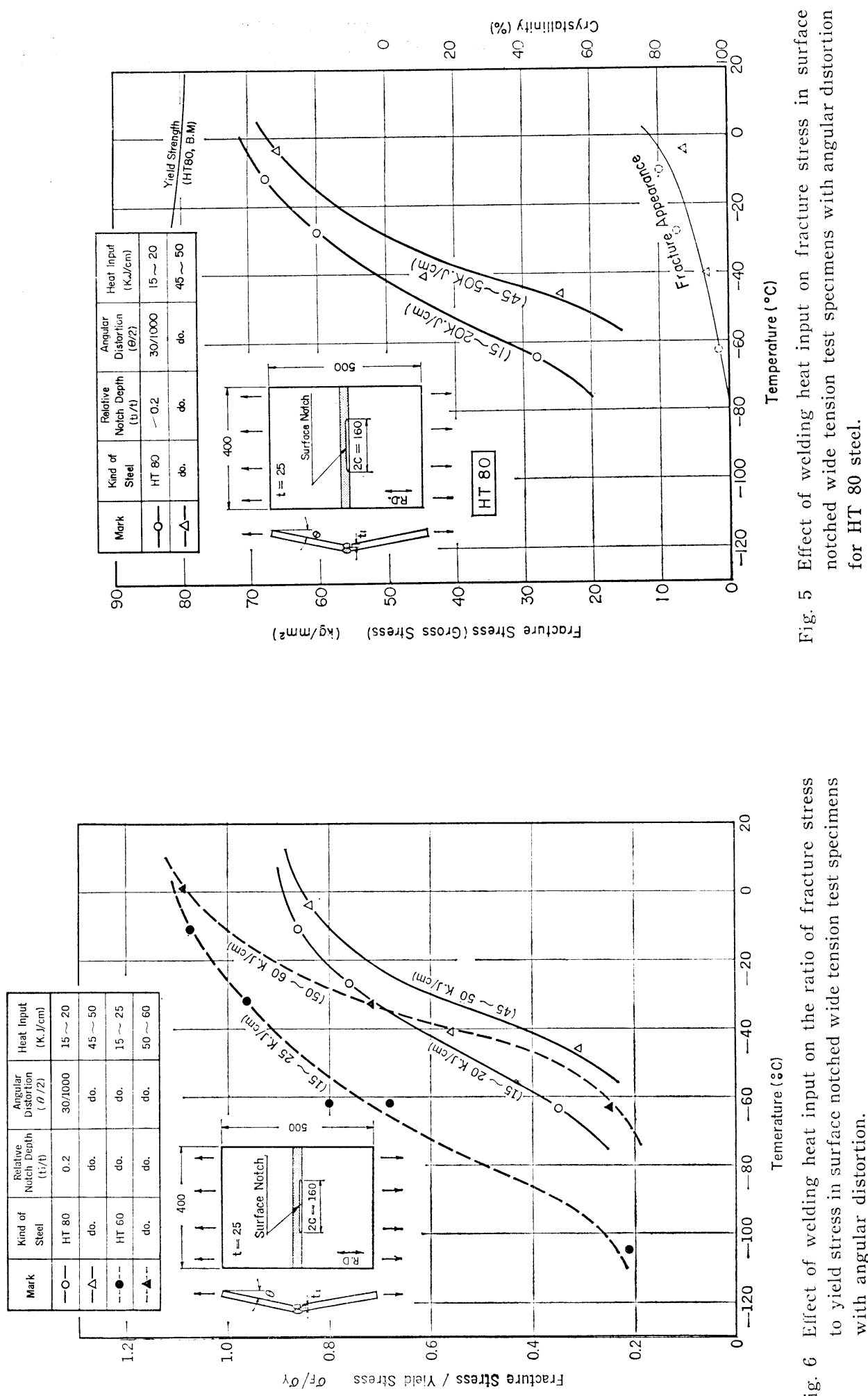

告

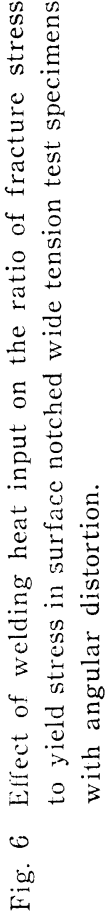



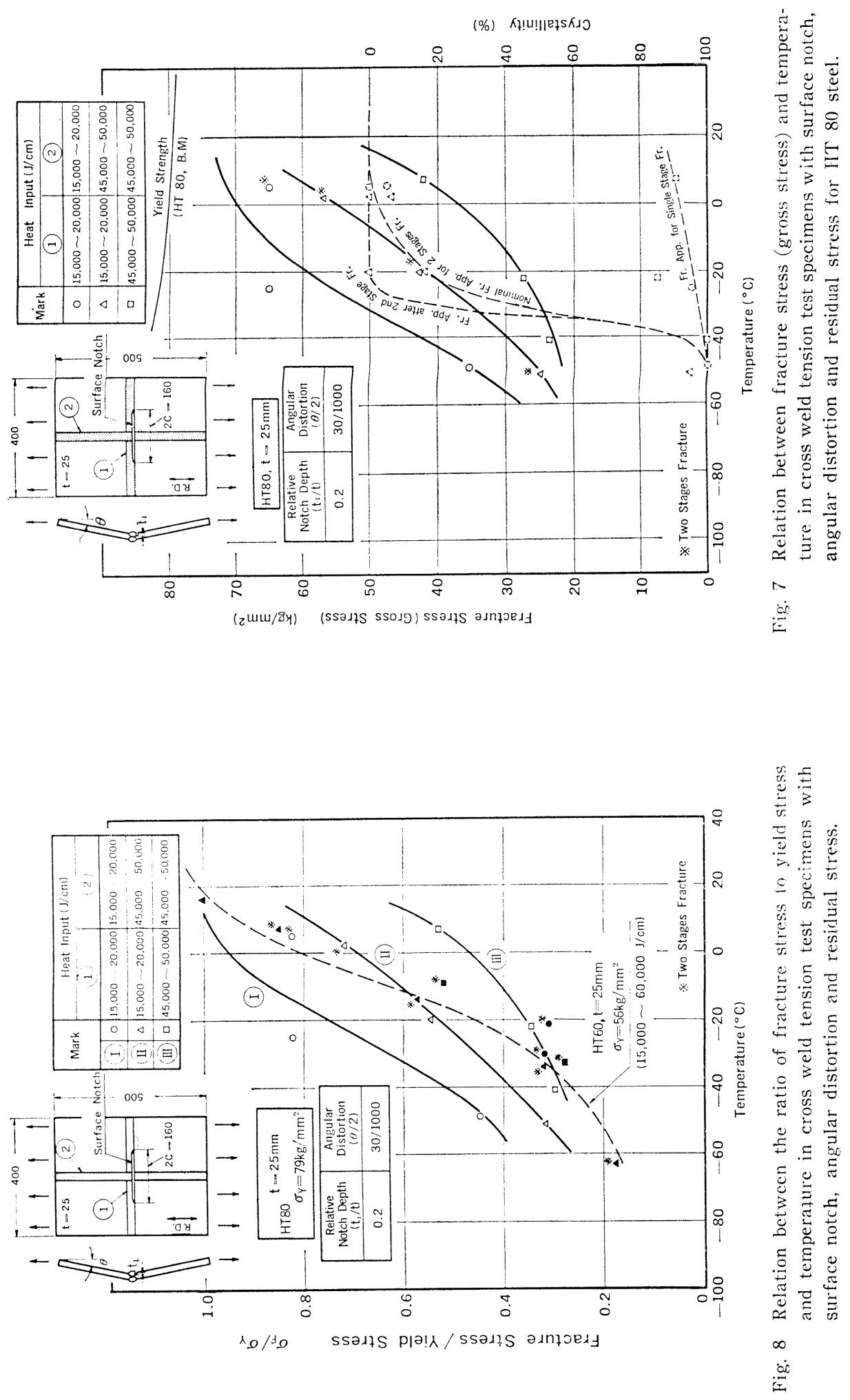
ほとんど無視し得る程度であつたが，HT 80 においては入熱の影響が顕著であるといえる。

また，破面率については，入熱の違いによる影響が認められず，常温においても脆性破面率が約 $90 \%$ だり， 遷移温度は $10^{\circ} \mathrm{C}$ 以上の高温域となつている。ただし, 破面率は, single stage fr. と 2 stages fr. とでは相異 し，後者の場合には破面趞移温度はかなり低温側に位置することがわかる。

なお，HT 80 における 2 stages fr. の現象は縦継手が大入熱の場合には, 主に推察されるが, これは水平継 手および縱継手の入熱による材質変化の影響が影著となるためと考えられ，HT 60 における現象とも符号して いる。

つぎに，公称破壊応力を降伏強さに対する割合で示すと Fig. 3 のようになるが，HT 60 と比較した場合にも HT 80 の両継手が大入熱の場合が最も低い值を示している。従つて，降伏比がより大となるHT 80 では，実際 の溶接施工に打ける入熱管理を政格に実施する必要があるとともに，脆性破壤を防止するための配慮がより重要 であることを示唆しているものと考壳られる。

\section{2 破壊力学の適用:よる破懐応力の推計}

限界応力集中度 (Critical Stress Intensity Factor) $K_{I C}$ の対数と緦対温度の逝数の間に治, 切欠先端の塑性 領域の比較的㹨い温度筙柬内で, $\log K_{I C}=-T_{0} / T_{K}+\log K_{I O}$ なる Arrenius 型の温度依存性があることが知ら れているが，本節では，HT 80 各試験片の破壞応力より $K_{I C}$ 值を算定し，この絬果に基づて $K_{I C}$ の温度㳖 存性を求めることとする2) 7)。

まず，角変形のない試験片の破壞灾うと $K_{I C}$ の関係については，（1）式のIrwin の棈円切欠に対する破壊 条件式が適用できる。

$$
\begin{aligned}
& K_{I C}=\left(\frac{1.2 \pi}{\Phi^{2}-0.212\left(\frac{\sigma}{\sigma_{Y}}\right)^{2}}\right)^{1 / 2} f(\gamma) \sigma t_{1}^{1 / 2}\left(=K_{P}\right) \\
& \text { ただし } t_{1} \text { =棈円切欠の深さ（短軸） } \\
& \sigma=\text { 一様負荷応力 } \\
& \sigma_{Y}=\text { 降伏応力 } \\
& \Phi=\text { 切欠深さ } t_{1} \text { と切欠長さの半分 } c \text { に関する楕円積分関数 } \\
& \Phi=\int_{0}^{\pi / 2} \sqrt{1-\left(\frac{c^{2}-t_{1}^{2}}{c^{2}}\right) \sin ^{2} \theta} \cdot d \theta \\
& f(\gamma)=\text { 無限板への修正係数 } \\
& f(r)=\sqrt{\frac{2 t}{\pi t_{1}} \tan \frac{\pi t_{1}}{2 t}}
\end{aligned}
$$

また，角変形のあるものについては，前報で示したように，引張による $K_{P}$ 值と偏心による曲げモーメントを 考慮した $K_{B}$ 値との和として表わされる。

$$
\begin{aligned}
K_{I C}=K_{P}+K_{B} & K_{B}=\left(\frac{1.2 \pi}{\Phi^{2}-0.212\left(\frac{\sigma}{\sigma_{y}}\right)^{2}}\right)^{1 / 2} \frac{Y_{B}}{\sqrt{ } 1.2 \pi} \cdot \frac{6 e}{t} \sigma t_{1}{ }^{1 / 2} \\
\text { ただし } & Y_{B}=1.99-2.47\left(\frac{t_{1}}{t}\right)+12.97\left(\frac{t_{1}}{t}\right)^{2}-23.17\left(\frac{t_{1}}{t}\right)^{3}+24.80\left(\frac{t_{1}}{t}\right)^{4} \\
e & =\text { 破壊時における試験片の偏心量 } \\
t & =\text { 板厚 }
\end{aligned}
$$

'1 $)$ （3）式を用いて, 実験值より各試験片の $K_{I C}$ を求めると Fig. 9 に示すようになる。

これによると, 切久のみの場合, 切欠に角变形が重畳した場合, さらに残留応力が重置した場合の $K_{I C}$ 值は

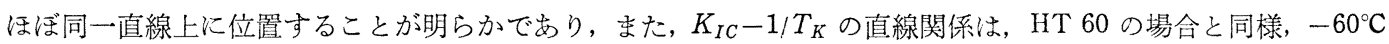
付近を境として傾斜の異なつたものとなつている。その理由としては, $-60^{\circ} \mathrm{C}$ 以上の温度域では, 塑性領域の 抎りおよび shear lip の影響が加わり, Irwin 流の fracture mechanics の適用には間題が残されよう。また， 残留応力の影響を加味した十字継手における $K_{I C}$ は，その影響が全く見られないが，この場合の材料が高強度 になる汪ど，相対的に残留応力が低くなること，切欠加工方法によるものと考えられる。なお，一6 $0^{\circ} \mathrm{C}$ 以上に 
(แ山) $7 ! 10 \Phi$
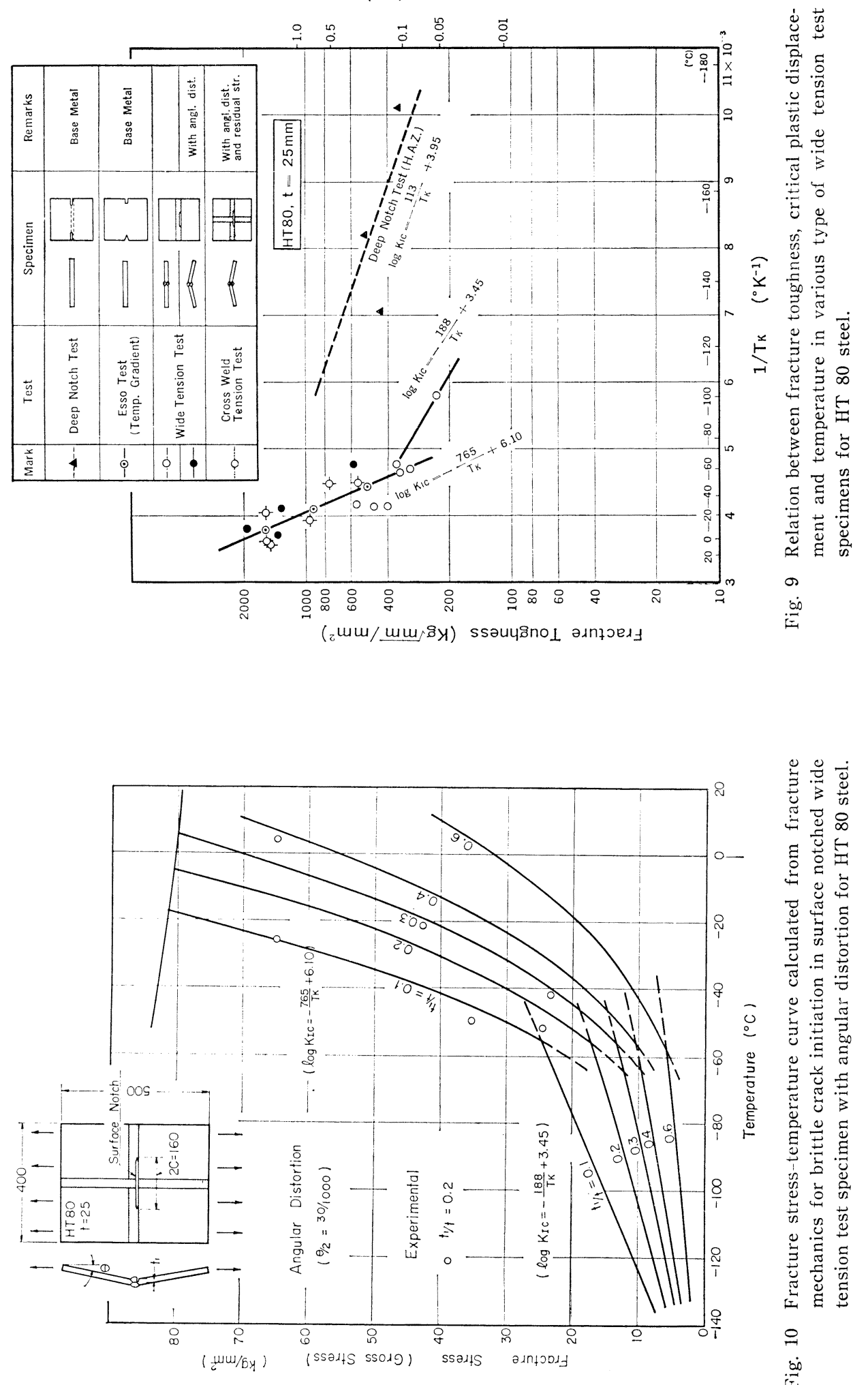

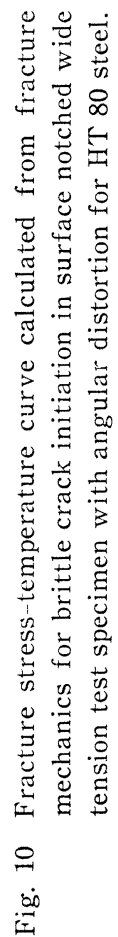


おける $\log K_{I C}$ と $1 / T_{K}$ の関 係法温度勾配型の ESSO 試稌 より得られる $K_{a c}$ (脆性破壊 の伝播停止特性を与兄る）に ほほ近い值を示している。

実験で得られた $\log K_{I C}-$ $1 / T_{K}$ 曲線の実喝式より逆汇， 十字継手試験汇和计万破填時 の公称破壊芯力之温度の関係 を計算より求めると，Fig. 10 に示すよらになる。

つぎに, 各試験片の切欠先 端にお战る塑性変位 $\Phi(c)$ は 次式で与光られるが

$$
\Phi(c)=\frac{\pi K^{2}}{2 \sigma_{y} E}
$$

各試験片の $\Phi$ crit とこれに 対与る脆性破面率との関係を 図示すると Fig. 11 のように なる。切久のみの試験片では $\Phi$ crit $=0.2 \sim 0.3 \mathrm{~mm}$ の範围 で，角変形付試験片および十 字継手圾験片では， $\Phi$ crit> 2 3 mm の範囲で破面の远 移がみられる。

\section{3 破面の観察}

（1）破面遷移温度につい $\tau$

各種の要因が重冝した広幅 引張試駼片の破面㟟移曲線打 よで小型試験の破面要移曲線 之広幅試験の破㯖応力条件々 の相関関係を Fig. 12 祘よび

Table 4 亿示す。広幅試駼片 の破面遥性温度（wTrs）快, 小型に比べ，かなり高温䁶に あり, 切欠, 届变形, 残留応 力が重畳した苛酷な条件下で の $\mathrm{w} \operatorname{Trs}$ は $+10^{\circ} \mathrm{C}$ 以上とな つている。しかし, この場合 中幅試騟としての Tipper 試 験片の破面要移温度とはかな り近似したものとなつている ことが注目される。一方， two stages fr. に打ける破面 逘移温度としては, single

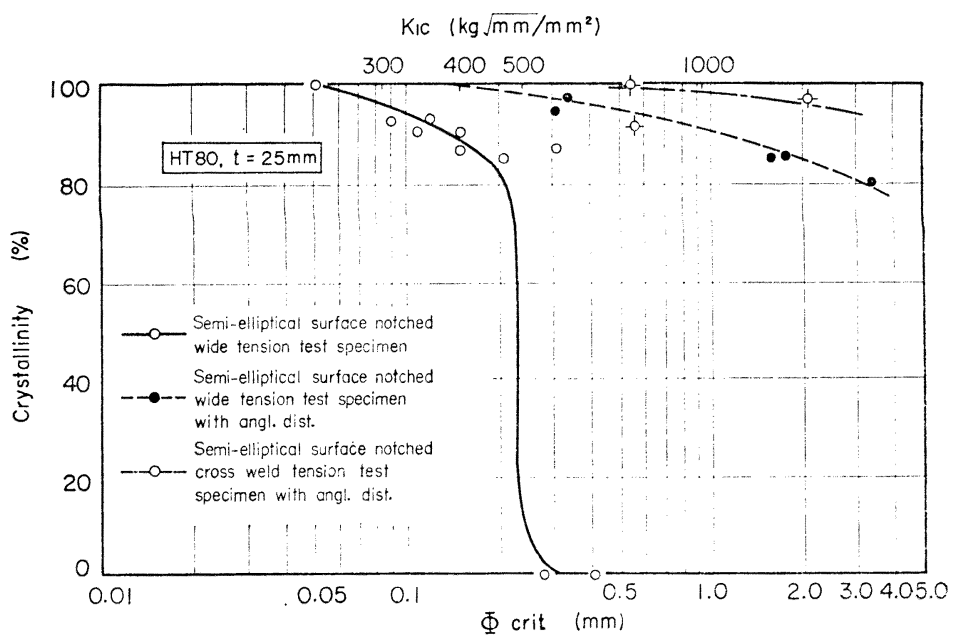

Fig. 11 Relation between crystallinity and critical plastic displacement $\Phi$ crit for various types of wide tension test specimens (HT 80 steel).

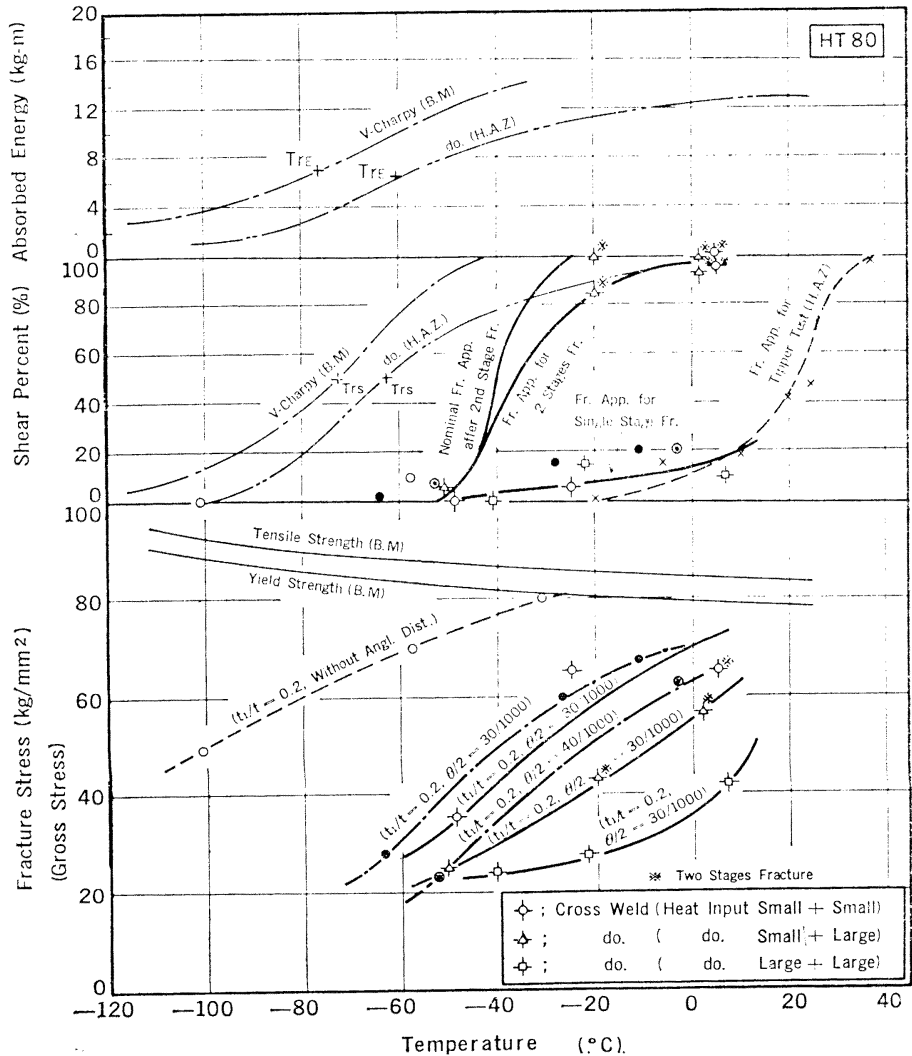

Fig. 12 Relation between fracture stress, shear percent, absorbed energy and temperature in various size test specimens for HT 80 steel. 
Table 4 Correlation of transition temperatures in various tests

\begin{tabular}{|c|c|c|c|}
\hline \multicolumn{3}{|c|}{ Transition Temperature $\left({ }^{\circ} \mathrm{C}\right)$} & \multirow{2}{*}{ Kinds of test } \\
\hline & HT 60 & HT 80 & \\
\hline vTrs & -57 & -63 & $2 \mathrm{mmV}$-Charpy Impact Test (H. A.Z.) \\
\hline wTrs & $-20 \sim-30$ & $0 \sim-30$ & W. T. T.*(without angular distortion) \\
\hline wTrs & -5 & $>0$ & do. (with angl. dist.) \\
\hline wTrs & +5 & $>+10$ & do. (with cross weld \& angl. dist.) \\
\hline wTrs & $-15 \sim-25$ & -30 & do. (for second stage fracture) \\
\hline${ }_{\mathrm{T}} \mathrm{Trs}$ & -18 & +22 & Tipper Test (H. A.Z.) \\
\hline $1 / 2 \sigma_{y} \mathrm{~T}_{\mathrm{aG}}$ & -4 & -25 & ESSO Test with Temp. Gradient (B. M.) \\
\hline NDT & -45 & - & NRL Drop Weight Test (H.A.Z.) \\
\hline FTE & -12 & - & do. $\quad\left(\mathrm{NDT}+60^{\circ} \mathrm{F}\right)$ \\
\hline
\end{tabular}

Remarks *; W. T. T. $=$ Wide Tension Test

stage に比べ約 $60^{\circ} \mathrm{C}$ 低温側を示すことが認 められ，恐らく貫通切久型広幅試験の破面䢬 移温度と汪ぼ一致するのではないかと推察さ れる。

なお，応力遷移温度との相関については， 後章で検討を試みることとする。

\section{（2）破面の樣相}

広幅試験片の脆性破壊破面の例を Photo. 1 および Photo. 2 に示す。

一般に, HT 80 では破面の切欠側に shear $1_{\text {ip }}$ の発生しているものが多く，亦た，溶接 ビードの層間状洸が明白に顕れているもの 等, HT 60 に比べると複雑な破面様相を示 しているものが多く観察された。

また arresting 現象については, 十字継 手試験片の縦継手が大入熱の場合に多く見ら れ，このことは，HT 60 場合の現象とも符 号している。

\section{4 溶接構造物における破埴防止策の検} 討

（1）構造物の設計条件之脆性破壞発生条 件との相互関係について

低荷重脆性破壞発生条件と実際構造物の設 計条件岕るいは使用条件との関係の 1 例とし て, Fig. 13 に HT 80 使用の常温高圧式球 形貯槽の設計応力条件 (使用温度 -10 $48^{\circ} \mathrm{C}, \sigma_{a} \fallingdotseq 29 \mathrm{~kg} / \mathrm{mm}^{2}$ ) 㧊よび耐圧試験条件 $\left(\sigma_{T}=1.5 \sigma_{a}\right.$, 水温) と実験で得られた破壊応 力条件との相対関係を示したが，供試鋼材は 切欠勒性の点で良好な特性を有しているにも かかわらず大入熱 (45,000〜50, 000 joule/ $\mathrm{cm})$ の場合に $10^{\circ} \mathrm{C}$ 前後の常温域での耐圧

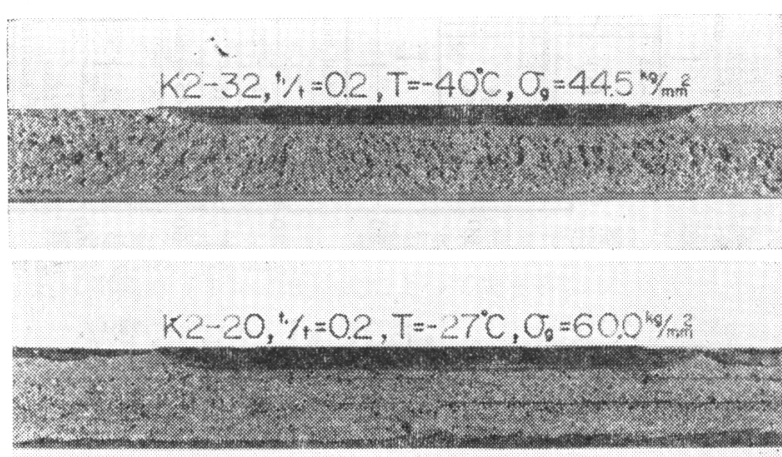

Photo. 1 Some examples of fracture appearences of surface notched wide tension test specimens with angular distortion.

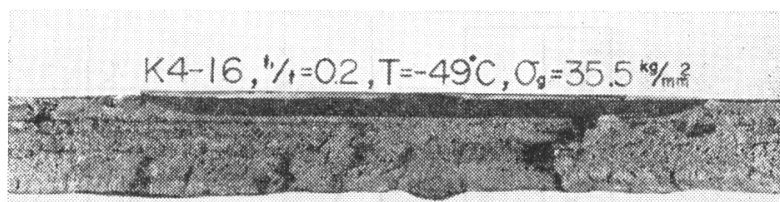

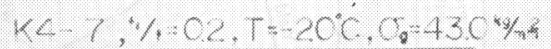

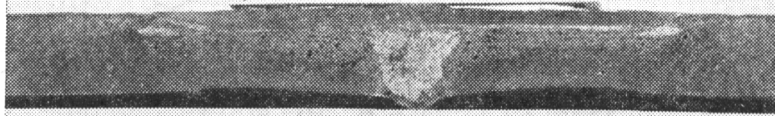

\section{$\mathrm{K} 4-10, " 1 / \mathrm{t}=02, T=-22^{\circ} \mathrm{C}, \mathrm{O}_{\mathrm{g}}=27.5 \mathrm{k} / \mathrm{m}$}

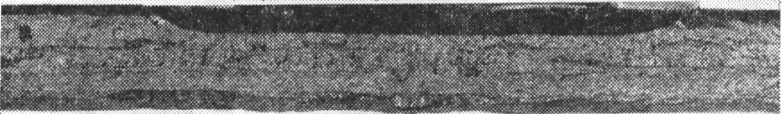

Photo. 2 Typical fracture appearances of surface notched cross weld tension test specimens with angular distortion. 

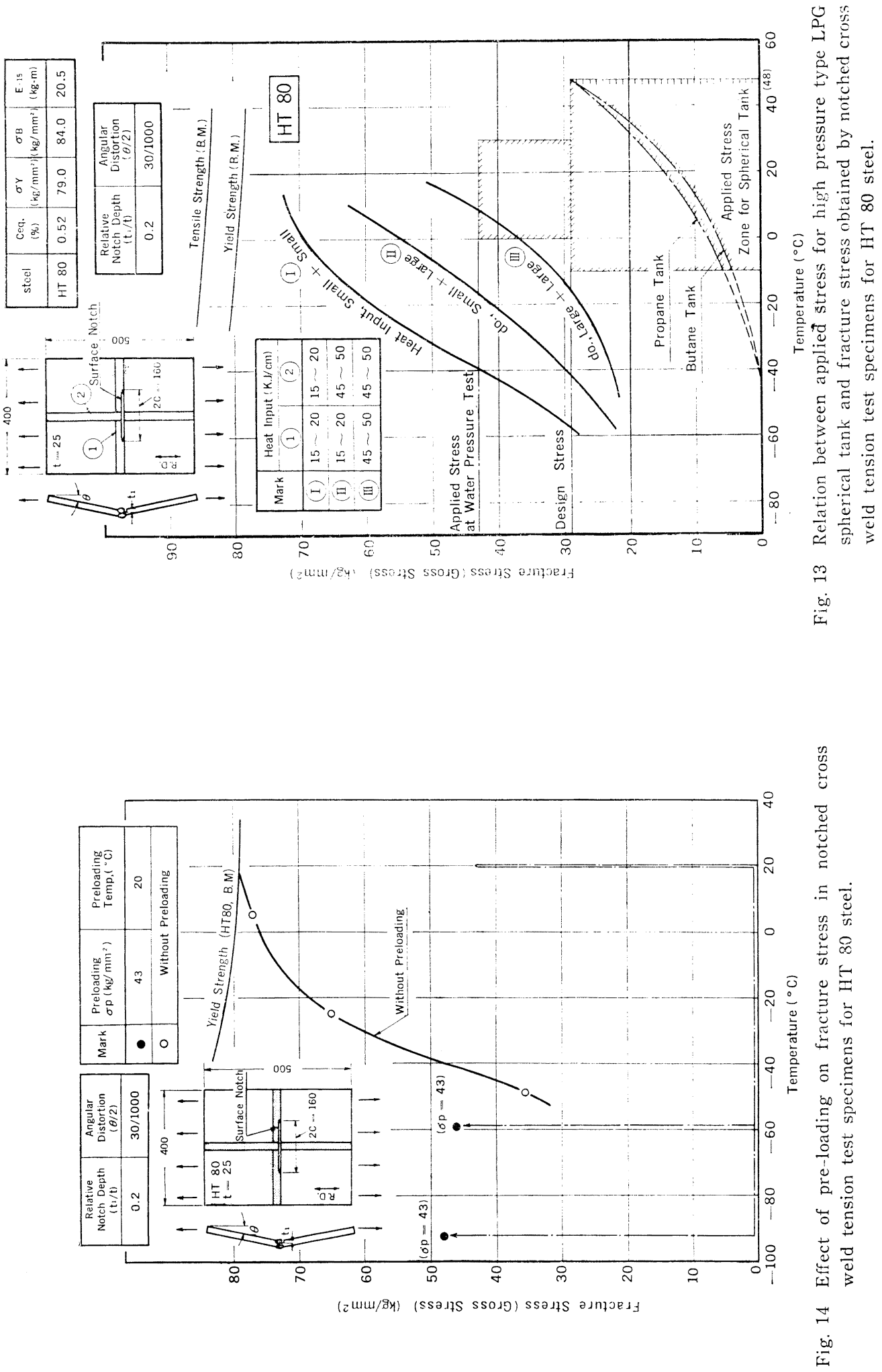


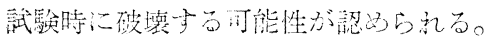

（2）予街霍による機栈的心力除上の効果汇ついて

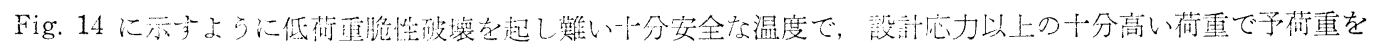

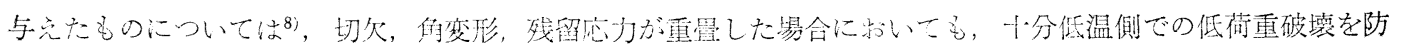

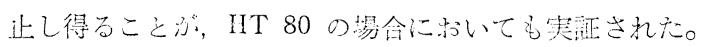

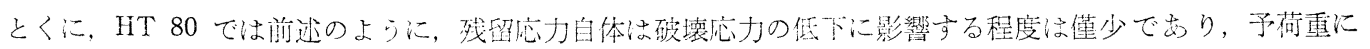

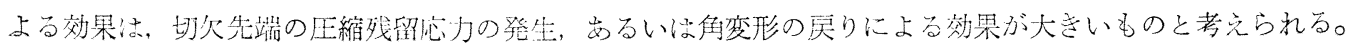

\section{5. 醋T 60 と HT 80 の試験結果を包含した総合的考察}

\section{1 非貫通切次よりの脆性破壊発生条件について}

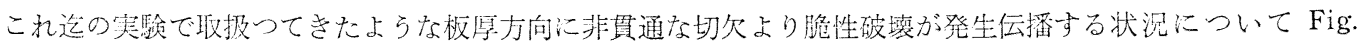
15 に示すよらないくつかの mode に分類することが出来る。すなわち

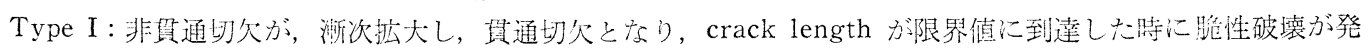
生伝播する。

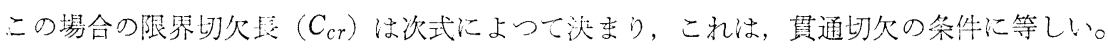

$$
\begin{aligned}
& K_{C}=\sqrt{\pi} C_{c r} \cdot f^{\prime}(r) \cdot \sigma_{f} \\
& K_{C}=\text { 貫通切次比沙る限界度力集中度 } \\
& f^{\prime}(r)=\text { 盤限板に対する板幅修正係数 }
\end{aligned}
$$

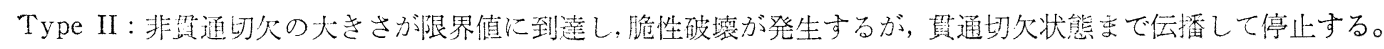
この場合の限界切久寸法は Irwin の楕门型とすれば前揭の（1）（3）式によつて決まる。

$$
K_{I C}=\left(\frac{1.2 \pi}{\Phi^{2}-0.212\left(\frac{\sigma}{\sigma_{Y}}\right)^{2}}\right)^{1 / 2}\left[f_{(\gamma)}+\frac{6 e \cdot Y_{B}}{\sqrt{ } 1.2 \pi \cdot t}\right] \sigma_{f^{t} t_{1}{ }^{1 / 2}}
$$

しかし， crack が板厚を貫通桩大した所で

$$
K_{a c}>\sqrt{\pi} \cdot c^{\prime} \cdot f^{\prime}(r) \cdot \sigma_{f}
$$

となり，伝播を停止する。

Type III : 非貫通切欠の大きさが限界值に到達し，脆性破壊が発生し，そのまま伝播する。

この場合は, Type II で crack が板厚を貫通抎大した所で

$$
K_{a c} \leq \sqrt{\pi \cdot c^{\prime}} \cdot f^{\prime}(r) \cdot \sigma_{f}
$$

で宓る。

以上，3つの Type に関係与方瑟因としては

(a) 部分切欠の艮さおよび深さ

(b) 板厚

(c) $K_{I C}, K_{C}, K_{a c}$ の各值の差

(d) 付加㐫力条件

などの影響が著しい。

Type I が起り易い例としては，（1）非貫通切欠としては，応力集中度も低く，脆性破壞の発生条件とはなり 得ないが，(2) fatigue などにより部分切欠が拡大貫通し，から，(3）切欠長さも十分長くなつて, 遂泎性破 壞を発生する場合で, 相対条件として, 対象となる (a) 部分切欠が長く, (b) 板厚が薄く, (c) $K_{I C} \cong K_{C}$, （d）切欠直上の局部的 stress raiser がない上らな場合が考光られる。

Type II が起る条件としては，（1）非貫通切久より脆性破壞を発生する程, 応力集中度は高かつたが, 切久が 貫通した状態では，（2）応力集中度が低下するような局部的応力集中条件があつたり，(3）切欠長さが㐫まり長 くなく, 脆性破壊が停止する場合で, 相対条件としては, 対象となる（a）部分切欠はやや短く, から（b）板 厚に対して切欠深さはかなり深く，（c） $K_{I C}<K_{a c}$ ，（d）切欠值上に残留応力などの局部的 stress raiser があ るような埸合が考光られる。

Type III の起る条件としては，（1）非貫通切欠より脆性破壞を発生し，かつ切欠が貫通した状態でも，（2）十 

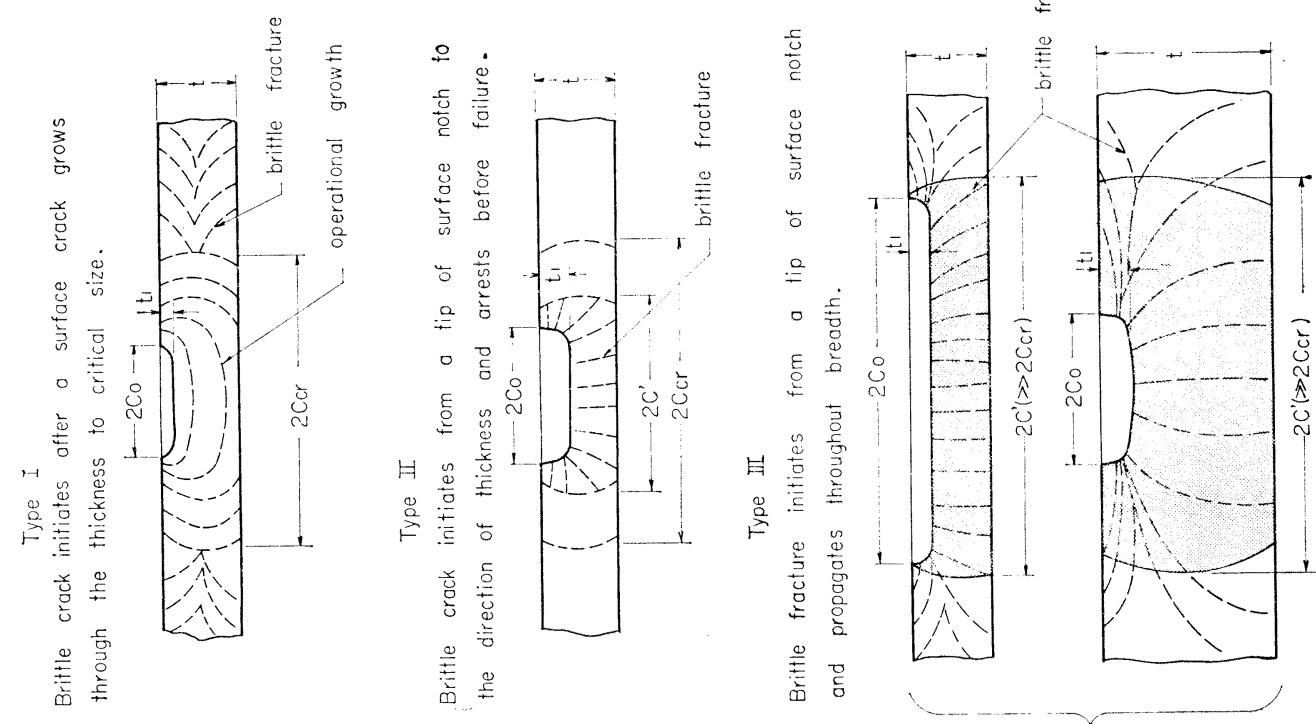

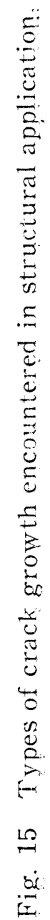
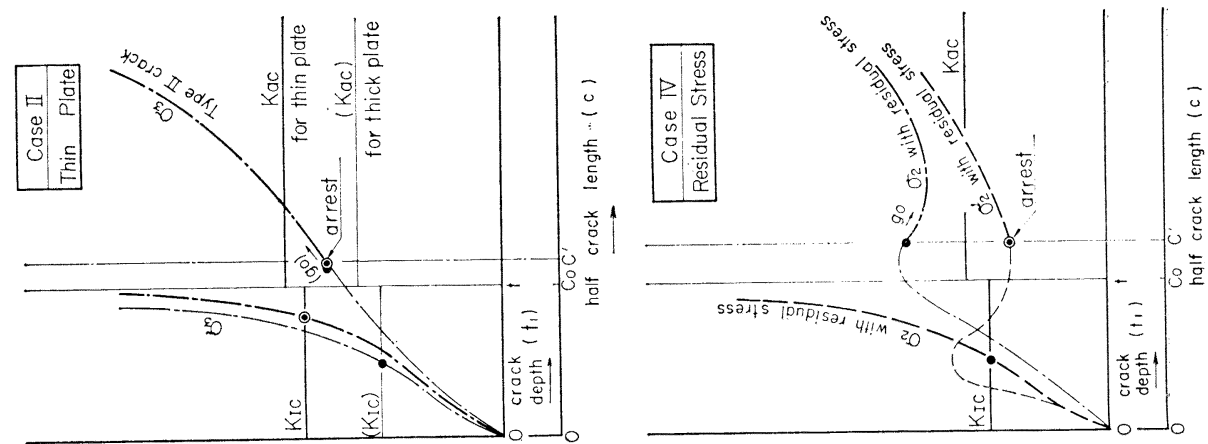

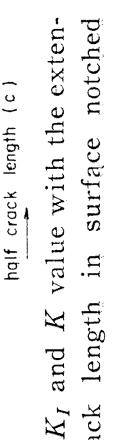
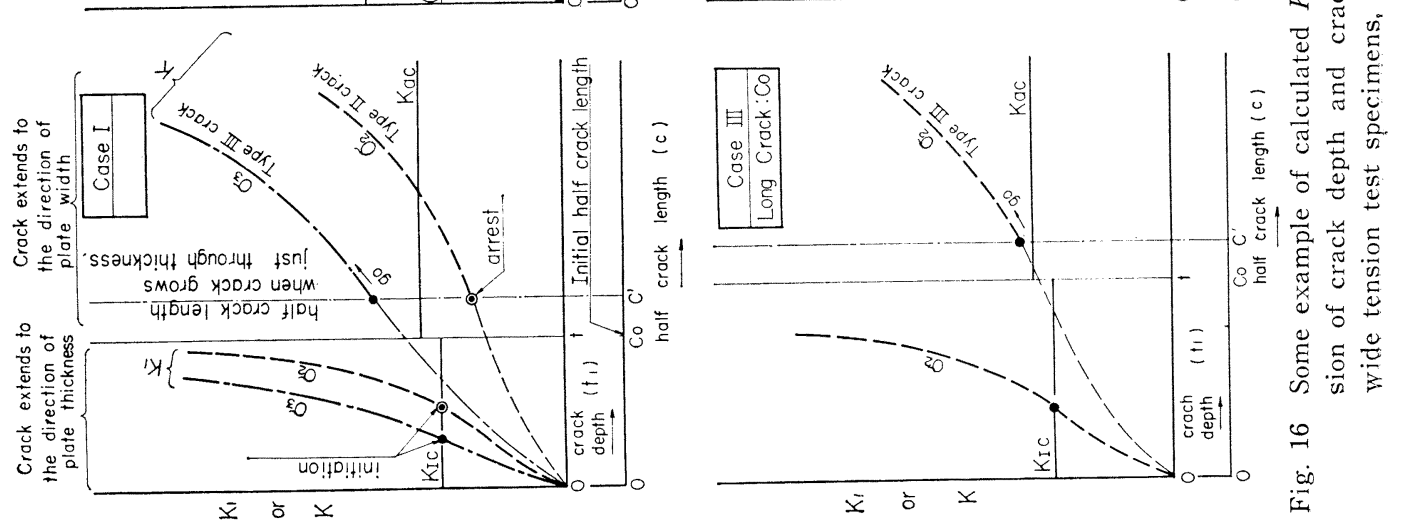
分な応力集中度の維持される状態で, 相対条件としては, 対象となる（a）部分切欠は長く，(b) 板厚は厚く, （c） $K_{I C}$ に比べ $K_{a c}$ は比較的小さく，（d）一様負荷荷重がかなり高いが, 局部的 stress raiser は切欠端に も影響をおよぼす範囲にあるなどの場合が考劣られる。

さて, Type I については, 元々, 貫通切欠の間題と考えられるが, Type II と Type III とは非貫通切久特 有の問題と考觉られるので両者の比較について検討することとする。

Fig. 16 は半楕円 crack が桩大する場合に $K_{I}$ または $K$ の変化について，2，3 例示したものである。Fig. 16 の横軸は crack の深さ $\left(t_{1}\right)$ およよ゙ crack の長さ $(c)$ を表わしているが, 表現として, $\left(t_{1}\right)$ 軸の尺度と $(c)$ , 軸の尺度とは, 板厚 $t$ と初期 crack の長さ $c_{0}$ とが, 同一位置に来るよう比例させている。

さて, Case I は一般的な場合で, ある stress level $\sigma_{2}$ では arrest し, Type II の破壊となるが, より高い stress level $\sigma_{3}$ では arrest せず, Type III の破壊となることを示している。

Case II は Case I 同様, める高い stress level $\sigma_{3}$ て脆性破壞が発生しても, 板厚が薄く, 板厚効果によつ て, 伝播停止限界灾力集中度が高いために arrest する例である。板厚効果について, たとえば金沢, 町田の 式们を適用すれば，下記の通りである。

$$
K_{a c}=K_{a c}(30) \cdot f(t)
$$

$$
\text { ただし， } \quad K_{a c}(30)=\text { 板厚 } 30 \mathrm{~mm} \text { に換算したときの } K_{a c} \text { 值 }
$$

$$
f(t)=\text { 板厚効果係数 }\left\{\begin{array}{l}
\frac{60}{t+5}-2, t \leq 10 \\
1-\frac{1}{20}(t-30), \quad 10<t<35 \\
0.75,35 \leq t
\end{array}\right.
$$

例光ば, $K_{a c}$ は板厚 $25 \mathrm{~mm}$ から, 板厚 $10 \mathrm{~mm}$ に薄くなれば 1.6 倍となる。 $K_{I C}$ についての板厚効果倸数に ついては，明らかでないが，仮に初期の割れ深さ $t_{1}=5 \mathrm{~mm}$ 一定の場合を仮定すれば, $t=25 \mathrm{~mm}$ で $t_{1} / t=0.2$, $t=10 \mathrm{~mm}$ で $t_{1} / t=0.5$ となり, 板厚効果を考虑したとしても， $t=10 \mathrm{~mm}$ の場合に $t=25 \mathrm{~mm}$ での破壊応力を 飛び抜沙た高い破壞灾力での破壤発生の可能性は少いと考光られる。したがつて, この場合薄板の方が arrest する可能性が大であると判断される。

Case III は, 初期龟裂垃さ $c_{0}$ が非常に大きい場合であり, この場合には板厚方向の $K_{I C}$ に比べ板幅方向の $K$ 值の上年が著しく, arrest しない。

Case IV は残留応力の方場合の例であり，亀裂が板厚方向貫通後も残留応力の影響が大であれば arrest が 起り難く, 逆に残留応力によつて $K_{I}$ の上昇が著しいため低荷重破偯を示しても, 残留応力の影響汸板幅方向に

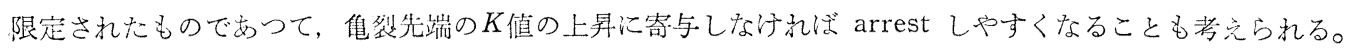

もちろえ, これらの条件の他, 材料の特性て上つて $K_{I C}$ 值と $K_{a c}$ 值とが著しく異なれば破壊様式は異ること 屾十分考兄られる。

Fig. 17 は上記の考光に基づいて，第 1 報 Fig. 23 において two stages fracture が発生した試験のうち， 試駼温度 $-10^{\circ} \mathrm{C}$ 付近のものを示したものである。

計算においては $c^{\prime}$ による若干の変動を考慮すると, この温度で快 $\sigma=35 \sim 40 \mathrm{~kg} / \mathrm{mm}^{2}$ 以下の応力で arrest する可能性があると推定され，この值は，ほぼ実験結果を説明し得ると考兄られよう。

これらの例は Type II の破壞に属するものであるが, 実用的な意義に抒いては, Type III の破壊が突発的で めり，極めて重大な事故につながると考光られる。すなわち、Type I, II の破壊は, たとえば貯槽などでは亀 裂部よりの漏洩などの損伤を伴うが，大事故に到るまえに龟裂発見の機会も多いと思われ，また構造物全体の破 澴に到る前に検知することも可能であろう。したがつて, Type III の破壊を最も恐れるとすれば, 下記の条件 での非貫通切欠よりの破壞発生を防止することが重要と考光られる。
（a）極めて長い非貫通切欠，または連続する可能性のある連をなす非貫通切欠の存在する埸合
(b) 板厚の厚い部材に非貫通切欠がある場合
(c) $K_{I C}$ に比べ $K_{a c}$ が比較的小さい低い温度条件下にある場合
（d）一様負荷荷重が大きくなる設計応力の高い構造物，すなわち強度の高い鋼材を使用した檏造物 


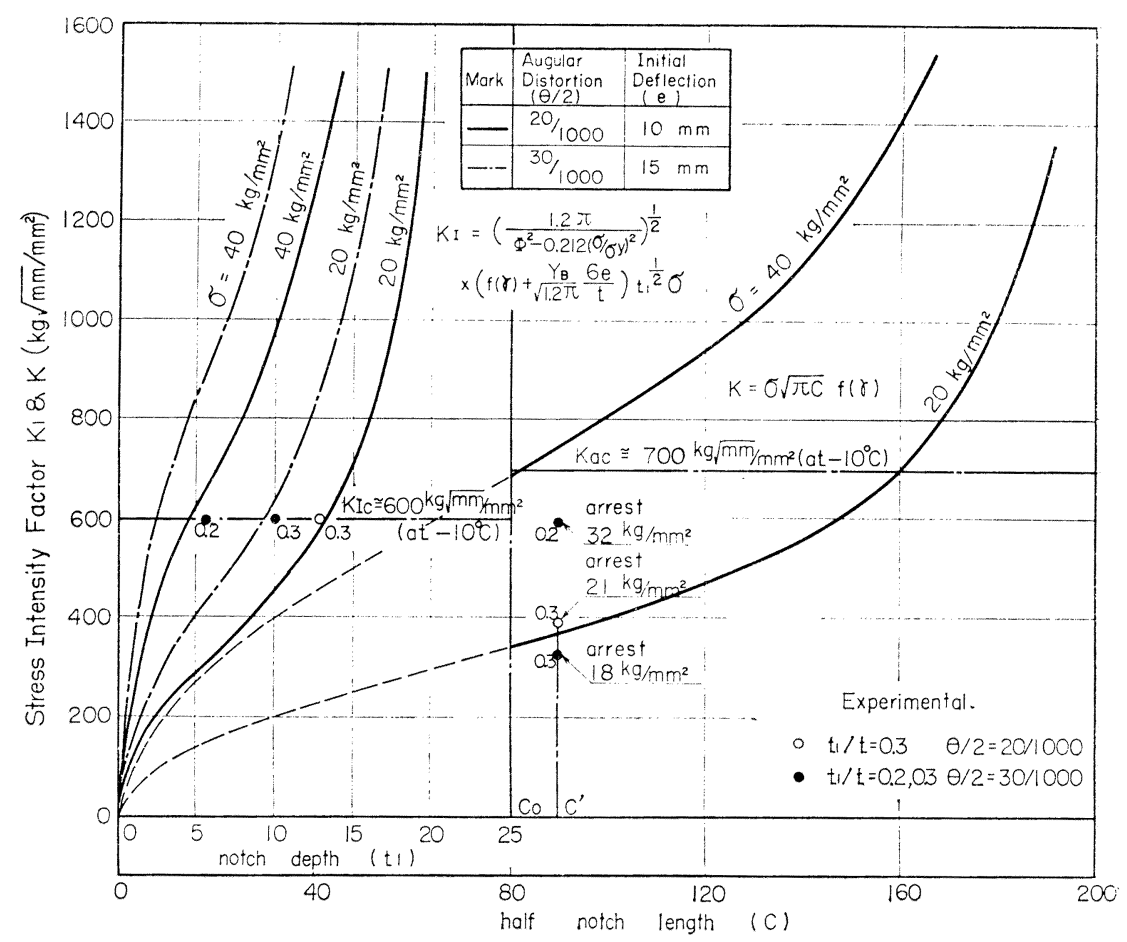

Fig. 17 Relation between $K_{I C}\left(K_{C}\right)$ and $K_{I}(K)$ with the extension of notch length in surface notched cross weld tension test specimen showing two stages fracture.

\section{2 応力遷移温度と破面遷移温度の関係について}

HT 60 と HT 80 の広幅試験結果について比較すると，まず，前述の上うに解変形のない切久のみの場合に は, HT 80 の応力遷移温度は高温側であり, また角変形付の場合にも, HT 80 の方がやや高温側に応力遷移が 認められたが，HT 60 との差は僅少である。すなわち，荷酷度の变化により HT 60 の応力遷移温度の移行が 大きいことを示している。なお，破面選移温度については角変形のない場合より $20^{\circ} \mathrm{C}$ 前後高温側に移行してい ることが認められる。

つぎに，残留応力の重畳を考慮した十字継手試験片においては，低入熱条件の場合にはHT 80 の方が応力遷 移温度はやや低温側に認められるが，大入熱になると，HT 80 の場合の少化が著しく，反つて高温側に応力暧 移温度が位置するようになる。また残留応力が重畳しない場合に対しては，HT 60 の応力要移温度の移行がや や大きく, この場合に HT 80 とほぼ同じ程度の応力遷移温度を示すことが認められだ。以上の結果より，切欠 付広幅引張試験の破面遷移温度と応力遌移温度の関係については, 下記の推論が考兄られる。

（a）一般に応力遷移温度は，破面遷移温度より低温側に表われる。

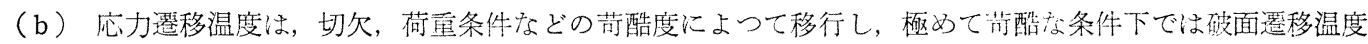
に接近する。

（c）この場合，苛酷度の变化に上る破面選移温度も若干移行（移行方向は応力選移と同一方向）するが，応 力遷移温度の移行に比べると僅少である。

（d）苛酷度を軽減させると応力遷移温度は低温側へ移行するが，移行温度の幅は，降伏比の高い高張力鋼澡 ど小さく，強度の低い鋼ほど大幅に低温側に移行すると考兄られる。

（a）（c）は一般的に認められている現象であるが，（d）については著者らの推定でめる。しかし，(d)の

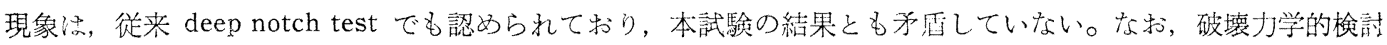
を加えれば以下のとおりとなる。 


$$
\begin{aligned}
\log K_{I C} & =\frac{-\alpha}{T_{K}}+\beta(\alpha, \beta=\text { 材料によつて定まる数值 }) \\
K_{I C}{ }^{2} & =A \cdot \sigma_{f}^{2}(A=\text { 苛酷度に相当 })
\end{aligned}
$$

ここで $\sigma_{f}=1 / 2 \sigma_{y}$ と皐けば

$$
\begin{gathered}
\frac{\partial T_{k}}{\partial A}=\frac{1}{A} \cdot \frac{\alpha}{\left(\log A+2 \log \sigma_{y}-\beta^{\prime}\right)^{2}} \\
\beta^{\prime}=\beta+\log 4
\end{gathered}
$$

ただし

したがつて， $\alpha, \beta$ が大差ないとすれば， $\sigma_{y}$ の大きい材料では $\partial T_{k} / \partial A$ が小さくなり，温度差が少ない。

なお， $\alpha, \beta$ について deep notch test の資料より見ると， $\alpha, \beta$ は材料によつて大幅に变わるが，ほぼ同一 系統の鋼材では低強度のもの活ど，一般に $\alpha, \beta$ が大きい傾向にあるようであり，この点よりも $\partial T_{k} / \partial A$ は低 強度のものほど大きくなる傾向が喼められる。

なお，溶接入熱の影響など材質变化を主体とした影響については別途考虑せねばならないものと考える。

\section{3 破壊力学よりの許容偏心量の推定}

これまで切欠の大きさ，角変形の影響について破壊力学の適用を試み，実験結果の考察を行なつてきたが，本 節では,さらに, この破壞力学より逆に，これらの影響を考察し実際構造物の施工に対する示唆としたい。

すなわち，破壞力学に従がえば，構造物の脆性破壊の発生条件の限界値を決定するものは $K_{I C}$ である。この $K_{I C}$ のある一定値の場合に切欠深さ, 角変形量と破 壊応力との限界関係を HT 60 材 $(t=25 \mathrm{~mm})$ につ いて計算したものを Fig. 18 に示す。これによれば いかに角变形の影響が大きいか理解できよう。

しかし，この角変形-偏心量を全くなくすること は実際上，不可能であり，むしろこの偏心量をいく らまで許容するかが問題である。

実際構造物の設計に用いられる許容応力として仮 りに $1 / 2 \sigma_{Y}$ を想定し，また，鋼材の板厚としては $t=10 \sim 100 \mathrm{~mm}$ の範囲の場合を想定して検討する。 すなわち Fig. 19 および Fig. 20 は, HT 60 材に ついて $K_{I C}=500 \mathrm{~kg} / \sqrt{\mathrm{mm}} / \mathrm{mm}^{2}$ として, 設計応 力で破壞が発生する時の板厚 $(t)$ と偏心量 $(e)$ の限界条件の関係を $t_{1} / t$ および $t_{1}$ をパラメーター として（1）（3）式より䛿し図示したもので女 る。

Fig. 19 から判かるよらに相対切欠深さ一定とし て考えた場合には $t_{1} / t \cong 0.2$ では厚板であつても限 界偏心量 $(e)$ の值はほぼ一定で $15 \mathrm{~mm}$ 程度であ るが, $t_{1} / t$ がさらに増加して $t_{1} / t \cong 0.6$ となると 90 $\sim 100 \mathrm{~mm}$ の厚板では $e=0$ であつても $\sigma_{f}=\sigma_{\mathrm{design}}$ となる。

なお， $K_{I C}$ に対する板厚効果については明らかで ないが, 一応前述の $K_{a c}$ に対する板厚効果係数 $f(t)$ と同じものを考えると図中の一点鎖線で示す関係が 得られる。

この場合には $t=20 \mathrm{~mm}$ 以下の薄板ではほぼ一定 した值となり厚板にくらべ薄板の方が許容偏心量が 大きく安全であることがわかる。

また，厚板においては板厚効果を考慮しない時よ

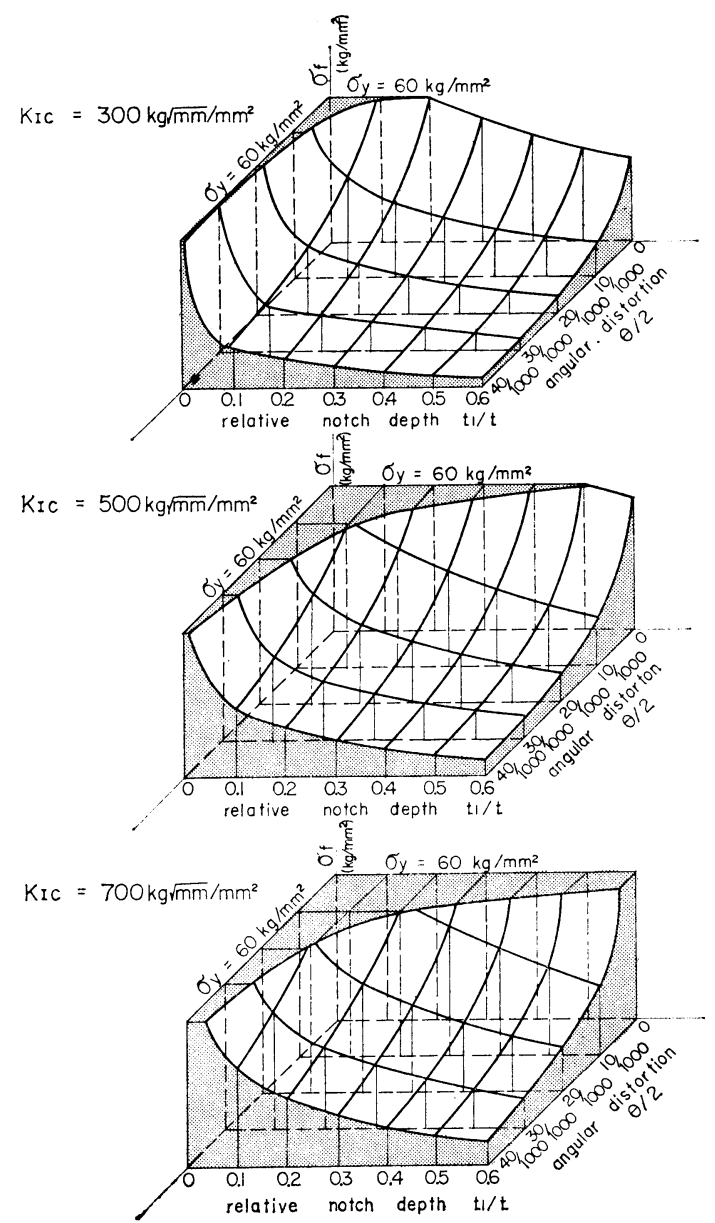

Fig. 18 Effects of relative notch depth and angular distortion on fracture stress in case of $K$ constant. 

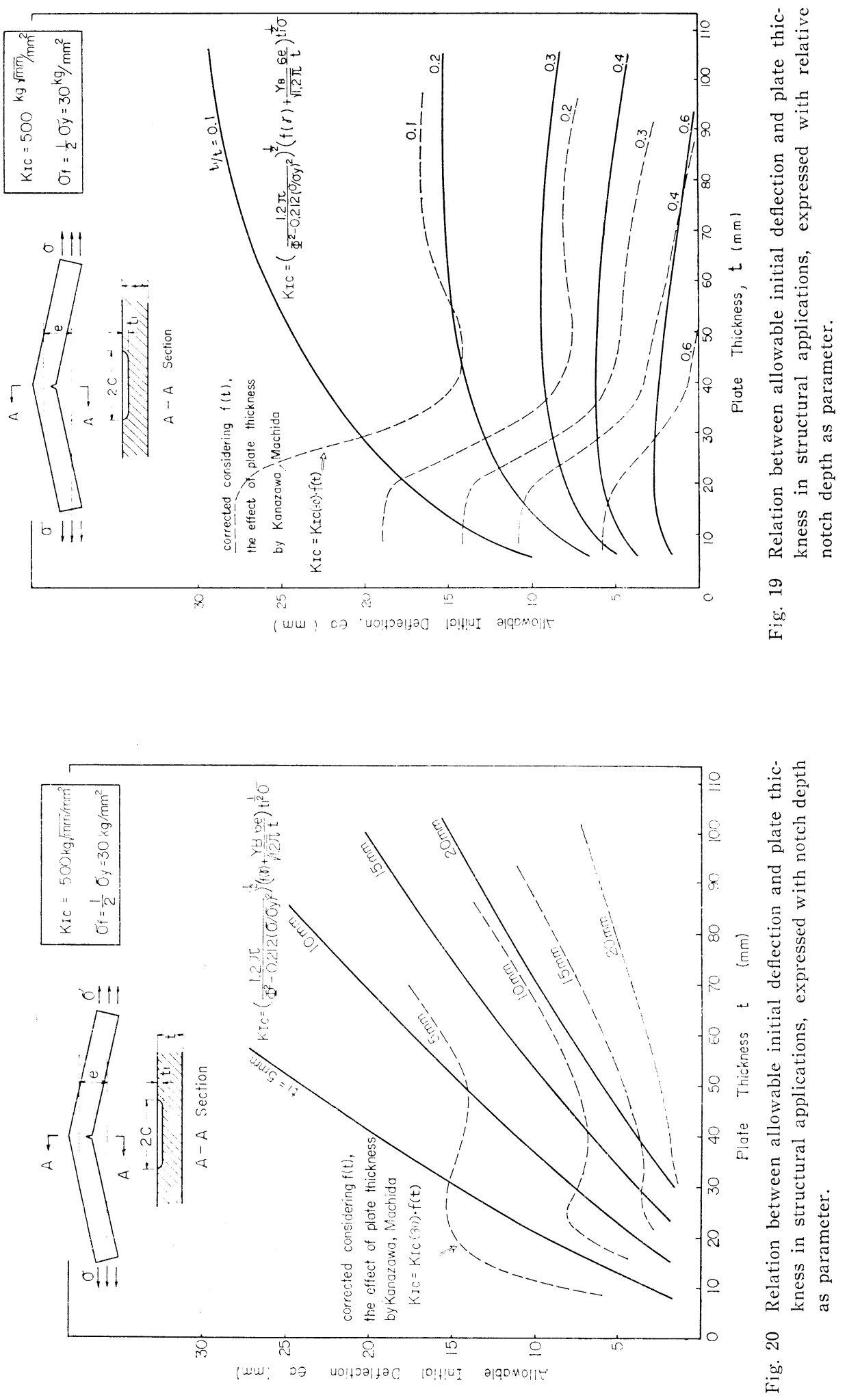
り著しく偏心量は減少し， $t_{1} / t=0.1$ で $e \cong 15 \sim 16 \mathrm{~mm}$ といつた值となつている。

なお，Fig. 20 のごとく，切深さの絶対值を一定として考虑すれば上記の関係はやや異なつた見解となるこ とは明らかであろう。

1968 年に改定された日本液化ガスプラント協会 (JLPA) の球型貯槽に対する施工規準に颃いて, この偏心量 を弦長 $1 \mathrm{~m}$ に対し，15 mm 以下におさえるよう規定しているが，実際の施工時めるいは開放検査などで発見さ れる止端割れの深さが, 数 $\mathrm{mm}$ 程度であることを考虑すると, Fig. 20 の結果からもこの值は適切なものと言 壳よ。

\section{6. 結 論}

引張強さ $80 \mathrm{~kg} / \mathrm{mm}^{2}$ 級調質高張力鋼の表面切欠付広幅引張試験を各種条件下で行なつた結果を検討し,ざら にこれを前報の結果 $\left(60 \mathrm{~kg} / \mathrm{mm}^{2}\right.$ 級調質高張力鋼）と比較し，これらを要約すれば，次のような結諭が得られ た。

（1）商用高張力鋼として，良好な切欠靶性を有し，その溶接継手部の切欠勒性も，実用上十分と考えられる 条件で, しかも, 切欠, 角变形, 残留応力が重量した状態で, 表面趾端切久部より, 実用温度域での低荷重脆性 破壊の発生を丽現した。

（2）切欠，角变形，残留応力などの個々の要因が，単独に作用する時は，低荷重破壊発生領域は極低温に限 られるが、それぞれの要因を重胃した場合には, その重量効果が認められ，応力遷移温度は破面遷移温度近くま で上昇する。。

（3）上記諸要因を変化させた場合に，HT 60 と HT 80 とでは，影響の程度が若干異り，HT 60 の方が応 力選移温度の移動幅が大きい。

（4）HT 80 においては，とくに溶接入熱の影響が認められ，45〜 $50 \mathrm{k} \cdot$ joule $/ \mathrm{cm}$ の高入熱条件で施工した溶 接継手に扮いて, $10{ }^{\circ} \mathrm{C}$ 前後の常温域で, 設計応力程度の低荷重脆性破壞を示した。

なおこのような材質的影響の効果については，切欠，角変形，残留応力などの主として施力条件として苛 酷作用与る紮因とは異つたものと考えられる。

（5）種々の忘力集中要因の重思して存在する場合でも，比較的高温度領域での予荷重などによる機械的応力 除去によつて低荷重破填発生領域を十分低湿側に移行させることができ，その有効性が実証できた。

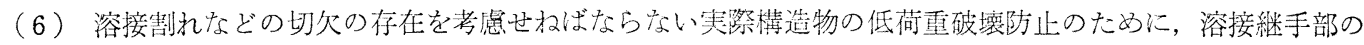
角变形を制限することは，东用上極めて有効で品る。この場合，試算によ机ば，板厚によつて制限条件をかなり 変化する必要が考劣られ，今後陦験的に明らかにされることがのぞるれる。

謝 辞

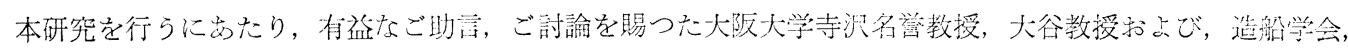
電気溶接研究委員会第 1 分科会の各委員に対し厚く就を中し上げます。また，本研究を実施するに当つて，ご 理解とご援助をいただいた川崎重工業 $\mathrm{KK}$ 吉田取締役，川崎製鉄 $\mathrm{K} \mathrm{K}$ 今井常務，高田鎘材技術部長，佐々木管理 部長，塔又技師の方々に暦くお礼を申し上げます。

また，本実験を遂行する上で，ご協打をいただいた川崎重工業 $\mathrm{KK}$, 溶接研究空, 山本室長, 寺井課長, 山田

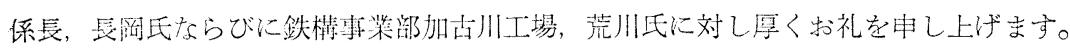

\section{参考文 献}

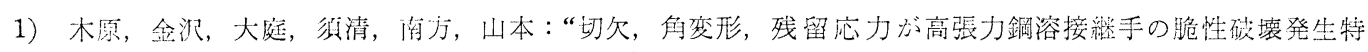

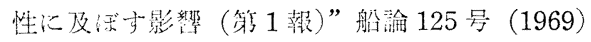

2) G. R. Irwin : "Crack Extension Force for a Part-Through Crack in a Plate". Journal of Applied Mechanics. Vol. 84 E, No. 4, December, 1962.

3) W.F.Brown, J. and J.E. Srawley : "Plane Strain Crack Toughness Testing of High Strength Metallic Materials”, ASTM Special-Technical Publication No. 410.

4) “Reports of a special ASTM Committee”, 1 st Jan. 1960, 2 nd May 1961, 5 th March 1964.

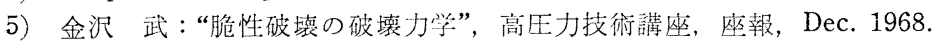

6) F. M. Burdekin, M. A. : "Initiation of brittle fracture in structural steels", British W. J. Dec. 1967. 


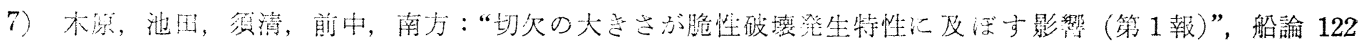
亳 (1967); “同上第 2 報”, 船論 123 号 (1968)

8) H. Kihara, K. Masubuchi, K. Iida and H. Öba: "Effect of Stress Relieving on Brittle Fracture Strength of Welded Steel Plates”, I. I. W. Doc. X-21-59, 1959.

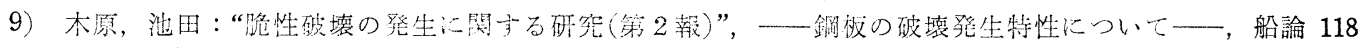
号 (1965)

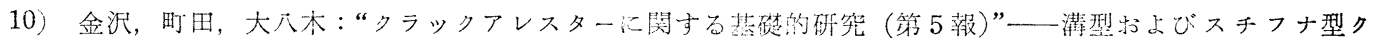
ラックアレスターの解析——, 船諭 122 号 (1967)

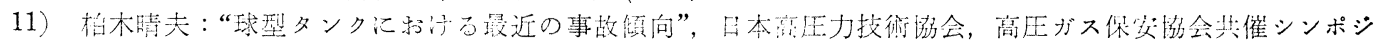
ウム, 1969. 